\title{
Influence Tax Avoidance, Company Size, Debt Ratio and Age against Debt Costs in Manufacturing Companies Listed on the Indonesia Stock Exchange in 2015-2017)
}

\author{
Dipa Teruna Awaludin \\ \{dipateruna@civitas.unas.ac.id\}, Universitas National, Jakarta, Indonesia.
}

\author{
Kartini \\ \{hanafikartini@fe.unhas.ac.id\}, Faculty of Economics and Business, Hasanuddin University, Makassar, Indonesia.
}

\section{Cepi Pahlevi}

\{cepipahlevi@gmail.com\}, Faculty of Economics and Business, Hasanuddin University, Makassar, Indonesia.

\author{
Madris \\ \{madriskandar@gmail.com\}, Faculty of Economics and Business, Hasanuddin University, Makassar, Indonesia.
}

\begin{abstract}
The purpose of this research to obtain empirical evidence about the influence of tax avoidance, firm size, leverage and firm age on cost of debt in companies listed in Indonesia stock exchange year 2015-2017.The data used is secondary data and samples of annual report from 25 manufacturing company listed in Indonesian stock exchange year 2015-2017 use purposive sampling and data analyzed use statistical tests descriptive, the classic, assumption linear regression analysis multiple, and test a hypothesis. Data analyzed by using software Statistical Package for the Social Sciences version 24. The results of studies show that the variable tax avoidance significant impact on cost of debt, while variable of firm size, leverage and firm age no significant impact on cost of debt.
\end{abstract}

Keyword:

tax avoidance, firm age, leverage, firm age and cost of debt

Article Received: 18 October 2020, Revised: 3 November 2020, Accepted: 24 December 2020

\section{Introduction}

Indonesia as developing countries has the state chief one of the revenues, the taxation revenue. In accordance with law KUP (general rules of taxation) article 1 law no. 28 year 2017[9], which states that taxes and other fees are arranged in force for the state purposes regulations to public welfare .State income tax was the largest in the company .Companies must pay tax in accordance with the tariff set by the directorate general of taxes, which will be used for the country development.

Best to judge a charge debt risk of tax evasion and benefits because banks usually becomes of long-term relationships with a borrowers and exclusive company have access to information. Characteristic the company is also included in factors influencing the cost of debt in this research (Permatasari, 2012)[11]. Characteristic first age of company, age able to illustrate company ability to companies survive in business.

In addition creditor also could assess the situation company of leverage or the debt ratio, the ratio of the show as far as which the debt, funded (Van-Horne, 2012)[20]. The less the ratio of leverage the more also can small risk for a creditor to invested in the company. Size of company/size of firm is characteristic of the last company to be used in this study. Companies size are of large size assets of company. If the 
CampaMore assets the higher company belief of a creditor to provide loans the. This because the company more having a bail when loan assets maturing.

We find that the cost of being over levered is asymmetrically higher than the cost of being under levered and that expected default costs constitute approximately half of the total ex ante cost of debt (Hanlon, 2010)[8].

The result of the research shows that Tax Avoidance (T-AV) has positive and significant effect on the cost of debt on manufacture companies. For independent variable others, manufacture companies' size and firms age have negative and significant. However, Leverage has positive and significant effect on cost of debt in companies. Therefore should add another variable closely related to tax avoidance and cost of debt (Coki et al. 2017)[3].

The significant positive relationship between company age and profitability is a confirmation of the learning by doing hypothesis. However, the positive relationship between size and profitability negates the hypothesis of structural inertia. Against the backdrop of the research findings, we recommend that the management should strive to increase the scale of operation of businesses and by implication, the size of the business to enhance improved reputation and attractiveness (Ofuan. 2016)[13].

\section{Research Methodology}

The charge is spending economically necessary for the production process. Calculations the cost is based on prevailing market price and at the time this process have occurred and has not happened. The cost of debt charge debts is the level of return required a creditor when provide funding to the company. All taxation is compulsory for all citizens to the state based on that its implementation can be imposed without something in return directly, whose outcome is used to government and national development.

Tax avoidance, tax avoidance is engineering tax affairs that still remain in a frame the terms of taxation (lawful). Are lawful Tax avoidance can occur on a buzzer provisions or written and are in the soul of the act of. Fiscal affairs committee of the organization for economic cooperation and development (OECD) mentioned there are three characters, tax avoidance namely. This kind of scheme be often exploit loopholes from regulations of taxation or applying legal for various purposes, and that is not which is actually intended by the. Regulation of taxation. Secrecy as well as a form of the scheme where generally consultants show a tool or way to do tax avoidance on the condition tax payers keeping as discreetly as possible. The size of the company big company will need big fund also used as a source of funding, so that the debt the company also would be great (martani, 2013)[2]. The size of this company was size or magnitude assets. The sizes of big company have the resources supporters that are bigger than the company that owns two sizes smaller. The debt ratio (leverage) the debt ratio (leverage) is the ratio which compare the total obligation with a total equity owned a company at the end of Leverage.

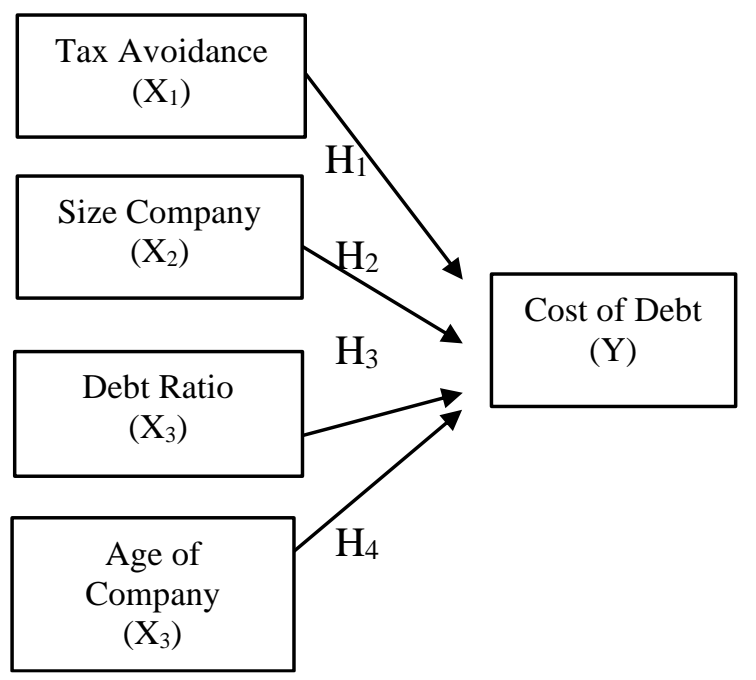

Fig. 1. Research Model

\section{Hypothesis}

Based on the skeleton analysis above, so a hypothesis that can be summed up by writer as follows: $\mathrm{H}_{1}$ : tax evasion influential about the cost of debt $\mathrm{H}_{2}$ : the size of the company influential about the cost of debt $\mathrm{H}_{3}$ : the debt ratio influential 
about the cost of debt $\mathrm{H}_{4}$ : age company influential about the cost of debt

\section{Method of Analysis}

Analysis method used in this study is the descriptive statistics consisting of the top of the classic, assumption linear regression analysis, multiple and testing the hypothesis by using software Microsoft excel and Statistical Package for the Social Sciences24. version Analysis method used in this study is the descriptive statistics consisting of the top of the classic, assumption linear regression analysis, multiple and testing the hypothesis by using software Microsoft excel and Statistical Package for the Social Sciences 24 version.

\section{Results and Discussion}

\section{Description of lab data}

Research population data used manufacturing enterprises Indonesia stock listed on the year 2015 BEI up to years old 2017. Company able to sample obtained in this research manufacturing firm some 25 with total data 75 report a finance company. The manufacturing firm has been listed in research on and during periods had not delisting. The focus of this study is to identify the effects tax avoidance, Size Company, the debt ratio and aged company to a charge debt.

\section{Regression equation is linear multiple}

Table 1. Coefficients ${ }^{\mathrm{a}}$

\begin{tabular}{|c|c|c|c|c|c|c|}
\hline \multirow{2}{*}{\multicolumn{2}{|c|}{ Model }} & \multicolumn{2}{|c|}{$\begin{array}{c}\text { Unstandardized } \\
\text { Coefficients }\end{array}$} & \multirow{2}{*}{$\begin{array}{c}\text { Standardized } \\
\text { Coefficients }\end{array}$} & \multirow[t]{2}{*}{$\mathrm{t}$} & \multirow[t]{2}{*}{ Sig. } \\
\hline & & B & Std. Error & & & \\
\hline \multirow{5}{*}{1} & (Constant) & ,056 & ,053 & & 1,067 & ,290 \\
\hline & Tax Avoidance & ,456 & 017 & ,972 & 26,782 & ,000 \\
\hline & Size Company &,- 006 &, 005 &,- 042 & $-1,257$ & ,213 \\
\hline & $\begin{array}{c}\text { Debt Ratio } \\
\text { Age of }\end{array}$ &, 000 &, 002 &,- 006 &,- 185 &, 854 \\
\hline & \multirow[t]{2}{*}{ Company } &,- 001 & ,000 &,- 046 & $-1,416$ & ,161 \\
\hline \multicolumn{6}{|c|}{ a. Dependent Variable: Cost of Debt } & \\
\hline
\end{tabular}

Source: Secondary data processed, 2019

\section{$\mathrm{COD}=0.056+0.456 \mathrm{TA}-0.006 \mathrm{SIZE}+0.000 \mathrm{LEV}-0.001 \mathrm{AGE}$}

From regression equation linear multiple above it can be seen that the constant value of 0.056 . This shows that if the independent variable has a value of 0 , then the probability of debt costs will be 0.056 .

Tax avoidance has a regression coefficient of 0.456 . This shows that for every increase of $\mathrm{Rp} 1$, it will increase the probability of debt costs by 0 , assuming that the value of other variables is fixed. Conversely, if tax avoidance drops by $\mathrm{Rp} 1$, it will reduce the probability of debt costs by 0.456 . Positive coefficient means that there is a positive relationship between tax avoidance and debt costs, the higher the tax avoidance, the higher the debt costs.

Company size has a regression coefficient of 0.006 . This shows that for every increase of $\mathrm{Rp} 1$, it will increase the probability of debt costs by 0 , assuming that the value of other variables is fixed. Conversely, if the size of the company drops Rp 1, it will reduce the probability of debt costs by 0.006. Negative coefficient means that there is a negative relationship between the size of the company and the cost of debt, the more assets the company has, the higher the cost of debt

Debt ratio has a regression coefficient of 0,000 . This shows that for every increase of $R p 1$, 
it will increase the probability of debt costs by 0 , assuming that the value of other variables is fixed. Conversely, if the debt ratio falls to $\mathrm{Rp} 1$, it will reduce the probability of debt costs by 0,000 . Positive coefficient means that there is a positive relationship between the debt ratio and the cost of debt, the higher the debt ratio, the higher the debt cost.

The age of the company has a regression coefficient of -0.001 . This shows that for every increase of Rp 1, it will increase the probability of debt costs by 0 , assuming that the value of other variables is fixed. Conversely, if the age of the company goes down $\mathrm{Rp} 1$, it will reduce the probability of debt costs by 0,000. Negative coefficient means that there is a negative relationship between the company's age and the cost of debt, the longer the company is on the Indonesia Stock Exchange is predicted to cause debt costs to decrease

\section{Test the coefficient of determination (adjusted} $\mathbf{R}^{2}$ )

Table 2. Model Summary ${ }^{\mathrm{b}}$

\begin{tabular}{|c|c|c|c|c|}
\hline Model & $\mathrm{R}$ & R Square & $\begin{array}{l}\text { Adjusted R } \\
\text { Square }\end{array}$ & $\begin{array}{l}\text { Std. Error of the } \\
\text { Estimate }\end{array}$ \\
\hline 1 &, $970^{\mathrm{a}}$ & ,942 & ,938 &, 02284 \\
\hline
\end{tabular}

Source: Secondary data processed, 2019

Testing shows the coefficient of determination reflects the adjusted square (Adjusted $\mathrm{R}^{2}$ ) as much as 0,938 or $93,8 \%$. This value represents that as much as $93,8 \%$ dependent variable or charge debt can be explained by tax evasion, the size of the company and the days of the debt ratio company. While the rest those are $7.2 \%$ described by other factors which this issue is not addressed in this research.

\section{Results of the fit and proper test a model}

Table 3. ANOVA ${ }^{\mathrm{a}}$

\begin{tabular}{llc|c|c|r|c}
\hline \multicolumn{2}{l}{ Model } & $\begin{array}{c}\text { Sum of } \\
\text { Squares }\end{array}$ & $\mathrm{df}$ & $\begin{array}{c}\text { Mean } \\
\text { Square }\end{array}$ & $\mathrm{F}$ & Sig. \\
\hline 1 & $\begin{array}{l}\text { Regressio } \\
\mathrm{n}\end{array}$ &, 590 & 4 &, 147 & 282,50 &, $000^{\mathrm{b}}$ \\
\cline { 2 - 7 } & Residual &, 037 & 70 &, 001 & & \\
\cline { 2 - 7 } & Total &, 627 & 74 & & & \\
\hline
\end{tabular}

a. Dependent Variable: Cost of Debt

b. Predictors: (Constant), Age of Company, Size Company, Debt Ratio, Tax Avoidace

Source: Secondary data processed, 2019

Based on output above known the value of significance to the influence of tax avoidance, the size of the company, debt ratio and the days of the company simultaneously to the cost of a debt by $\mathrm{f}$ 282,501 test of the significance of 0,000 smaller \& it; $\alpha 0,05$. This means, tax avoidance the size of the company, the debt ratio and the days of companies together had an influence on a charge debt. 


\section{Statistical Test Results $\mathbf{t}$}

Results of the hypothesis $t$ show the significance different on each independent variable on dependent variables. Here is the result test t. Based on table, 1 above and the testing of hypotheses as follows.

\section{Hypothesis $\mathrm{H}_{1}$}

Tax avoidance influences from the (table 1), a charge debt in table it can be seen that tax avoidance have the regression coefficient 0.456 and significance of $0,000 \& \mathrm{it} ; 0,05$, So $\mathrm{H}_{1}$ received, meaning tax avoidance significant to a charge debt.

\section{Hypothesis $\mathrm{H}_{2}$}

$\mathrm{H}_{2}$ : the size of the company influential about the cost of debt from (the table 1) it can be seen that the size of the company obtain the regression coefficient of $-0,006$ and significance of 0,213 \&gt; $0.05 . \mathrm{SoH}_{2}$ rejected, which means the size of the company not significant about the cost of debt.

\section{Hypothesis $\mathrm{H}_{3}$}

$\mathrm{H}_{3}$ : the debt ratio to depend on the cost of debt based on from table 1, table can be seen that the debt ratio obtain the regression coefficient of 0,000 and significance of $0,854 \mathrm{\& gt} ; 0,05$. Then $\mathrm{H}_{3}$ denied, which means the debt ratio will not affect the cost of debt.

\section{Hypothesis $\mathrm{H}_{4}$}

$\mathrm{H}_{4}$ : age company led to a charge debt from the table 1 it can be seen that age companies have a regression of $-0,001$ and significance of 0,161 ; 0,05 \&gt. So $\mathrm{H}_{4}$ rejected, which means life will not affect the company a charge debt.

\section{Conclusions}

1. Tax Avoidance has a significant effect on Debt Costs for manufacturing companies listed on the Indonesia Stock Exchange in 2015-2017.

2. The size of the company has no effect on the debt costs of manufacturing companies listed on the Indonesia Stock Exchange in 20152017.

3. Debt Ratio has no effect on Debt Costs for manufacturing companies listed on the Indonesia Stock Exchange in 2015-2017.
4. The age of the company does not affect the cost of debt in manufacturing companies listed on the Indonesia Stock Exchange in 2015-2017.

\section{References}

[1] Beatty..Auditor and The Underpricing of Initial Public Offering. The Accounting Review. Vol. LXIV. No. 4.(1989)

[2] Chasbiandani, Tryas dan DwiMartani., Pengaruh Tax Avoidance Jangka Panjang Terhadap Nilai Perusahaan.SNA XVI Banjarmasin. (2013).

[3] Coki et al. Effect Of Tax Avoidance, Size Of The Company, Leverage, Age Of The Company On Cost Of DebtIn Manufacturing Companies Listed In Indonesia Stock Exchange. Advances in Economics, Business and Management Research (AEBMR), volume 46 1st Economics and Business International Conference 2017 (EBIC 2017)

[4] Erniawati, Ika..Analisis Pengaruh Tax Avoidance terhadapBiaya Utang dan KepemilikanInstutional. Published Skripsi. Universitas Muhammadiyah Surakarta. Surakarta.(2014)

[5] Graham, J.R., \& Tucker, A. 2006. Tax shelters and corporate debt policy. Journal of Financial Economics 81, 563-594

[6] Gumanti, Tatang Ari. Earning Management: SuatuTelaahPustaka, JurnalAkuntansi dan Keuangan, vol.4,no.2, p 181-192 (2000).

[7] Halim, Abdul. IcukRanggaBawono dan Amin Dara,.PerpajakanKonsep, Aplikasi, Contoh dan StudiKasus. Jakarta: SalembaEmpat.(2014)

[8] Hanlon, Michelle dan Shane Heitzmen. A review of tax research. Jounal of accounting and economics no. 50, hal. 127-178 (2010).

[9] Kup, Undang-Undang, Dan Peraturanpelaksanaannya Kementerian Keuangan Ri Direktort Jende Ral Pajak Direktorat Penyuluhan, Pelayanan, 
Danhubungan Masyarakat Direktur Penyuluhanpelayanan Dan Humas 2013

[10] Lim,YD.Tax Avoidance, Cost Of Debt and Shareholder activism:Evidance from korea. Journal of bangking and finance, Depok.(2011).

[11] Permatasari, V. Marlinda..PengaruhProfitabilitas,

Solvabilitas, Ukuran Perusahaan TerhadapLamanya Waktu Penyelesaian Audit (Audit Delay) Pada Perusahaan Manufktur Yang Terdaftar di Bursa Efek Indonesia. JurnalAkuntansi dan Auditing. Vol 9. No.1 (2012)

[12] Purwati, L. dan Setiyarini..Mekanisme Corporate Governance, ManajemenLaba dan Kinerja Perusahaan.UniversitasBrawijaya.(2010)

[13] Opuan et al. Firm Age, Size and Profitability Dynamics: A Test of Learning by Doing and Structural Inertia Hypotheses. Business and Management Research Vol. 5, No. 1; 2016

[14] Rakhimsyah, LeliAmanah. Pengaruh Keputusan Pendanaan, KebijakanDividen Dan Tingkat SukuBungaTerhadap Nilai Perusahaan. JurnalInvestasi. Vol. 7 Hal. 31-45. Yogyakarta.(2011).

[15] Sartika, Widya. Analisis HubunganPenghindaranPajakTerhadapBi ayaHutang Dan KepemilikanInstitusionalSebagaiVariabel Pemoderasi. Depok: Universitas Indonesia (2012).

[16] Simanjuntak, P.D.L.,\& Sari, R. L. Analisis PengaruhReturn On Asset, Net Profit Margin, Earning Per Share terhadapReturn Saham pada Perusahaan Perbankan yang Terdaftar di BEI. JurnalEkonomi dan Keuangan, 2 (7), hal.423-434 (2014).

[17] Suwito, Edy dan Herawaty. Analisis PengaruhKarakteristik Perusahaan TerhadapTindakanPerataanLaba Yang Dilakukan Oleh Perusahaan Yang
Terdaftar Di BEJ. Simposium Nasional Akuntansi VIII Solo.(2005).

[18] Soon et al. The Effect Of Debt Choice On Firm Value. The Journal of Applied Business Research - January/February 2017. Volume 33, Number 1

[19] Trisnawati, R., PengaruhInformasiProspektusTerhadap Return Saham di Pasar Perdana.Tesis Program PascaSarjana UGM, Yogyakarta (1998).

[20] VanHornePRINSIP PRINSIP MANAJEMEN KEUANGAN JAMES C VAN HORNE EDISI 13 BUKU 1, Salembaempat 2012

[21] Wahidahwati.

PengaruhKepemilikanManajerial dan

KepemilikanInstitusional pada

KebijakanHutang Perusahaan:

SebuahPerspektifTheory Agency. Simposium Nasional Akuntansi IV.(2001) 